\title{
Histomorphology, oLH and hCG receptors, and testosterone secretion in vitro in Rambouillet rams from lines in which females had been selected for low or high reproductive rate
}

\author{
H. Cardenas ${ }^{*}$, J. G. Berardinelli ${ }^{\dagger}$, P. J. Burfening and R. Adair \\ Department of Animal and Range Sciences, Montana State University, Bozeman, MT 59717, USA
}

\begin{abstract}
The objective of this study was to determine whether gross or histomorphological components of the testes, capacity and dissociation constants $\left(K_{d}\right)$ of testicular oLH and hCG receptors, and gonadotrophin-stimulated testosterone secretion in vitro differed among Rambouillet rams from lines selected for low or high female reproductive rate and from rams of a random-bred control line. Lines had been selected for approximately 20 years. Data were collected from 22-month-old rams during the late breeding season. Rams among lines did not differ $(P>0.05)$ in gross testicular characteristics or most histomorphological characteristics. However, the percentage volume of interstitial vascular tissue was greater $(P<0.05)$ for rams from lines selected for low female reproductive rate than for rams from lines selected for high female reproductive rate. Receptor sites per Leydig cell and binding capacities of oLH and hCG receptors per testis, per gram of parenchyma, and per milligram of membrane protein did not differ $(P>0.05)$ among lines. The $K_{d}$ values for oLH and hCG receptors did not differ $(P>0.05)$ among lines; however, receptor sites per Leydig cell, capacities of testicular parenchyma to bind gonadotrophin and $K_{\mathrm{d}}$ values were higher $(P<0.05)$ for oLH than for hCG receptors. Total oLH- and hCG-stimulated testosterone secretion in vitro did not differ $(P<0.05)$ among lines. In conclusion, selection for or against reproductive rate in Rambouillet ewes has not altered gross or most histomorphometric characteristics of the testes of male offspring, with the exception that selection against reproductive rate increased the proportion of testicular volume occupied by vascular tissue within the interstitium. Furthermore, selection has not altered total oLH- and hCGstimulated testosterone secretion in vitro or the affinity and capacity of oLH and hCG receptors of the testes of male offspring.
\end{abstract}

\section{Introduction}

Breeds of sheep that differ in reproductive rate display positive correlations between traits of female reproductive rate and certain male reproductive characteristics such as testicular diameter (Land, 1973; Knight, 1984) or serum concentrations of LH (Thimonier and Pelletier, 1972; Land and Carr, 1975; Carr and Land, 1975). On the basis of such relationships, it was hypothesized (Bindon and Turner, 1974; Land, 1974) that certain aspects of male and female reproduction may be controlled by the same physiological factors that in turn are controlled by genes common to males and females. Chubb (1992) reported that genes controlling testis size are not directly associated with the $Y$ chromosome. Therefore, it is possible that selection based upon a sex-limited characteristic of either sex would produce changes in genetically correlated characteristics of the opposite sex.

*Present address: Department of Animal Science, The Ohio State University, 2029 Fyffe Road, Columbus, OH 43201, USA.

${ }^{\dagger}$ Correspondence and reprint requests.

Revised manuscript received 21 March 1994.
Data that support this hypothesis are as yet equivocal for females from lines in which males had been selected for or against reproductive endocrine responses or testicular traits (Haley et al., 1989, 1990; Matos and Thomas, 1992). Studies that evaluated reproductive endocrine responses and certain testicular characteristics of rams from lines of sheep in which females had been selected for different reproductive rates indicated little or no correlated responses in male offspring (Bindon et al., 1985; Hochereau-de Riviers et al., 1990a; Curry et al., 1993).

Most studies in this area have focused upon the relationship between characteristics of female reproductive rate as the criterion for selection and male reproductive traits such as $\mathrm{LH}$ or FSH concentrations, scrotal circumference, testicular diameter, and testicular mass. However, the effects of selection for female reproductive rate upon histomorphological and endocrinological characteristics of the testis have not been well documented.

Two lines of Rambouillet sheep that differ in reproductive rate were established by applying selection to a female sex-limited trait (Schoenian and Burfening, 1990). The selection 
process for establishing these lines has induced a change in the ovulation rate without affecting embryonic mortality (Schoenian and Burfening, 1990). The fact that an ovarian trait has been altered by selection led us to hypothesize that perhaps selection within these lines had induced correlated changes in testicular morphology and physiology in rams of these lines. The objectives of this study were (i) to determine whether selection for or against female reproductive rate in Rambouillet sheep had altered scrotal circumference, testis mass, testis tone and histomorphological components of the testicular parenchyma, and (ii) whether there were differences in histological components, to determine whether they were reflected in changes in either the capacity or affinity of testicular oLH and hCG receptors, or the ability of testicular parenchyma to secrete testosterone in vitro in response to gonadotrophin of mature male offspring.

\section{Materials and Methods}

\section{Animals and trials}

Rambouillet rams from lines in which ewes had been selected for either high (HL) or low (LL) reproductive rates, and Rambouillet rams from a random-bred control line (CL) were used in this study. Two trials were performed in consecutive years. Lines had been selected for female reproductive rate for 19 (Trial 1) and 20 (Trial 2) years. The details of the establishment, selection procedure, nutritional management and handling of these lines have been described by Schoenian and Burfening (1990). Each trial began during the first week of December and ended during the last week of February. At the start of each trial rams were 22 months of age and rams from each line were allocated randomly into three blocks to be orchidectomized at the beginning (first 3 weeks), middle (second 3 weeks), and end (third 3 weeks) of each trial. This method was used as a means to evaluate whether time (season) interacted with the type of line to bias the results of this experiment.

\section{Scrotal circumference, tone and orchidectomy}

The scrotum of each ram was shaved and the testes pushed towards the bottom of the scrotum to measure scrotal circumference at its widest point. After measuring the scrotal circumference, the pressure on the testes was released and the tone of each testis was determined by applying a tonometer (Lane Mfg Inc., Denver, $\mathrm{CO}$ ) to the external scrotal surface of the medial anterior area of each testis. Immediately thereafter, each ram was bilaterally orchidectomized under a surgical plane of anaesthesia induced and maintained with i.v. infusion of thyamallyl sodium into one jugular vein $(4 \%$ in $0.9 \%$ sterile saline, Bio-Ceutics Laboratories, Inc., St Joseph, MO). In Trial 1, the mass of each testis was recorded after removing the epididymis and tunica albuginea. In Trial 2, only the mass of the left testis was obtained because the right testis was prepared for perfusion fixation to evaluate histomorphological characteristics.

\section{Testis perfusion and slide preparation}

In Trial 2, the right testis of each ram was perfused immediately after orchidectomy by a procedure modified from
Glauert (1975). Perfusions were performed at $22^{\circ} \mathrm{C}$ through the testicular artery at a point close to the caput epididymis with $3 \%$ glutaraldehyde: $1 \%$ formaldehyde solution in $0.075 \mathrm{~mol}$ cacodylate buffer $1^{-1}$. The perfused testis was cut transversely into three parts: top, middle and bottom. Four $2 \mathrm{~mm} \times 2 \mathrm{~mm} \times 4 \mathrm{~mm}$ pieces were cut from each part and fixed overnight at $4{ }^{\circ} \mathrm{C}$ by immersion in buffered $2 \%$ glutaraldehyde. The pieces were then postfixed in buffered $1 \% \mathrm{OsO}_{4}$ for at least $2 \mathrm{~h}$, dehydrated in ethanol and embedded in araldite epoxy resin 502 . Five thin sections ( $1 \mu \mathrm{m}$ ) were cut from each block of embedded tissue and stained with Toluidine blue and basic fuchsin as described by Hoffmann et al. (1983). Two of the five sections from each block were chosen at random and photographed at $\times 125$ magnification using a light microscope. Details of two representative areas of the interstitium within each area included in the photomicrographs taken at $\times 125$ were then photographed at $\times 1250$ magnification.

\section{Stereology}

The total areas occupied by seminiferous tubules, interstitium and cross-sectional areas of seminiferous tubules were determined in the photomicrographs taken at $\times 125$. These measurements were then used to estimate the proportions of the volume of the testis (volume percentages) occupied by seminiferous tubules and interstitium, as described by Lunstra and Schanbacher (1988), and seminiferous tubule diameters $\left(A=\pi r^{2}\right)$, respectively.

Areas occupied by Leydig cells with and without nuclei, vascular tissue and all other structures of the interstitium collectively were measured in the photomicrographs taken at $\times 1250$. These determinations were used to estimate the volume percentages of each of these components of the interstitium and for the whole testis (Lunstra and Schanbacher, 1988). Cross-sectional areas of Leydig cell nuclei were also determined in the photomicrographs taken at $\times 1250$. Areas were measured directly from photomicrographs using a digitizer pad (Kurta ${ }^{(\mathbb{R})}$ IS/ONE, Phoenix, AZ) and calculations were performed by a computer using Sigma-Scan ${ }^{(\mathrm{III})}$ (Jandel Scientific, Corte Madera, CA).

Leydig cells and Leydig cell nuclei were assumed to be round and their volumes were obtained by first calculating the diameter from the cross-sectional area $\left(A=\pi r^{2}\right)$, adjusting the diameter according to Abercrombie (1946), and then using this corrected value to calculate the volume $\left(V=4 \pi r^{3} / 3\right)$.

The number of Leydig cells per gram of parenchyma was calculated by dividing the total volume of Leydig cells in $1 \mathrm{~g}$ of parenchyma by the Leydig cell volume (Allrich et al., 1983). A similar procedure was used to calculate the number of Leydig cells per testis. The specific gravity of the testicular parenchyma of each ram was determined and the average value of 1.04 was used for all calculations of testicular volume because a preliminary analysis demonstrated that specific gravity did not differ $(P>0.05)$ among lines.

\section{Testosterone secretion in vitro}

Immediately after orchidectomy, the tunica albuginea of the left testis was removed and one longitudinal half of the 
parenchyma was processed for evaluation of testosterone secretion in vitro. The other half of the parenchyma was frozen at $-20^{\circ} \mathrm{C}$ for the later assay of $\mathrm{oLH}$ and $\mathrm{hCG}$ receptors. Testicular parenchyma was processed for stimulation of testosterone secretion in vitro using the procedure of Berardinelli et al. (1989). Incubations were performed under an atmosphere of $5 \% \mathrm{CO}_{2}: 95 \% \mathrm{O}_{2}$ for $4 \mathrm{~h}$. Tissue was placed into flasks containing ME 199 medium (Cellgro; Mediatech, Washington, DC). The ME 199 medium in each flask was discarded and replaced three times with fresh medium at 15-min intervals before adding the gonadotrophins. The time from orchidectomy to the time when tissue rinsing began was approximately $40 \mathrm{~min}$. Tissue rinsing was necessary because it removed residual testosterone and probably gonadotrophins present in the fluid accompanying the tissue mince that could interfere with gonadotrophin-stimulated testosterone secretion in vitro and its evaluation (Berardinelli et al., 1989).

\section{Gonadotrophins and dosages}

hCG was used to stimulate testicular tissue in Trial 1 and both hCG and oLH were used in Trial 2. Ten minutes after tissue rinsing, hCG (US Biochemical Corporation, Cleveland, $\mathrm{OH}$ ) or oLH (NIDDK-oLH-I-3, Bethesda, MD) was added to flasks containing tissue in ME 199. Dosages of hCG were 0 , $0.025,0.25$ and 2.5 iu ME $199 \mathrm{ml}^{-1}$. Dosages of oLH were 0 , $0.13,1.3$ and $130 \mathrm{ng} \mathrm{ml}^{-1}$. Dosages of each gonadotrophin were prepared in ME 199 immediately before use, evaluated in quadruplicate, and added to each flask in $100 \mu \mathrm{l}$ aliquots. Dosages of oLH were equivalent on a molecular basis to dosages of hCG. Equivalencies were calculated taking the molecular mass of oLH as $28.3 \mathrm{kDa}$ and that of hCG as $37 \mathrm{kDa}$ (Sairam et al., 1988) and the equivalence of 15000 iu of hCG per mg of the hormone. Thus the concentrations of gonadotrophins tested were $0,4.6,46$ and $4600 \mathrm{pmol} \mathrm{l}^{-1}$.

\section{Sampling and testosterone radioimmunoassay}

Samples $(300 \mu \mathrm{l})$ of ME 199 were taken from each flask just before addition of gonadotrophin $(0 \mathrm{~h})$ and after $1,2,3$ and $4 \mathrm{~h}$ of incubation for testosterone determination. Testosterone was assayed without extraction by a radioimmunoassay validated in our laboratory (Byerley et al., 1990). Assay sensitivity was $20 \mathrm{pg} \mathrm{ml}^{-1}$. Interassay coefficients of variation for pools of samples that inhibited binding at 29 and $75 \%$ were 4.5 and $9.2 \%$, respectively, and intra-assay coefficients of variation for these pools were 4.9 and $9.9 \%$, respectively.

\section{$o L H$ and $h C G$ receptor assays}

lodination grade oLH (NIDDK-oLH-I-3, Bethesda, MD) and hCG (hCG no. CR-125, NICHD, NIH, Bethesda, MD) were labelled with ${ }^{125}$ I (New England Nuclear, Boston, MA) by the lactoperoxidase method and purified by gel filtration chromatography in Sephadex G-75 columns (Pharmacia, Uppsala). Hormones were eluted from columns with $25 \mathrm{mmol}$ Tris- $\mathrm{HCl}$ $1^{-1}$ (pH 7.5) containing $10 \mathrm{mmol} \mathrm{MgCl}_{2} \mathrm{I}^{-1}$ and $1 \mathrm{mg} \mathrm{BSA}$ $\mathrm{ml}^{-1}$. Elution fractions that had at least $70 \%$ of the total radioactivity in the TCA precipitate were used for the assays.
Specific activities of each hormone, based upon the percentage of incorporation in TCA precipitants, were $27.4 \mu \mathrm{Ci} \mu g^{-1}$ and $38.9 \mu \mathrm{Ci} \mu \mathrm{g}^{-1}$ for [ $\left.{ }^{125} \mathrm{I}\right]$-labelled oLH and [ $\left.{ }^{125} \mathrm{I}\right]$-labelled hCG, respectively.

Testicular membranes for radioreceptor assays were prepared by a modified procedure from Sairam et al. (1988). Briefly, frozen testicular parenchyma was thawed overnight at $4^{\circ} \mathrm{C}$. All further processing of membrane preparations was performed at this temperature. Approximately $25 \mathrm{~g}$ of testicular parenchyma was weighed, cut into small pieces with scissors, homogenized using a homogenizer (Brinkmann Instruments $\mathrm{Co}$.), and then filtered through four layers of gauze. Homogenizations were carried out in $50 \mathrm{ml}$ of Tris- $\mathrm{HCl}$ buffer $\left(25 \mathrm{mmol} \mathrm{l}^{-1}, \mathrm{pH} 7.5\right)$ containing $25 \mathrm{mmol}$ sucrose $1^{-1}$

The filtrate was centrifuged initially at $500 \mathrm{~g}$ for $15 \mathrm{~min}$; the supernatant was then recovered and centrifuged at $30000 \mathrm{~g}$ for $30 \mathrm{~min}$. The pellet was resuspended in Tris- $\mathrm{HCl}$ buffer ( $25 \mathrm{mmol} \mathrm{l}^{-1}, \mathrm{pH} 7.5$ ) and centrifuged again at the same speed. Centrifugations were carried out at $4^{\circ} \mathrm{C}$. Pellets were resuspended in Tris- $\mathrm{HCl}$ buffer $\left(25 \mathrm{mmol} \mathrm{l^{-1 }}\right)$ containing $10 \mathrm{mmol}$ $\mathrm{MgCl}_{2} \mathrm{I}^{-\mathrm{I}}$. Protein concentrations of membrane suspensions were determined with the $\mathrm{BCA}^{\mathbb{R}}$ Protein Assay (Pierce, Rockford, IL), using BSA as the standard. Increasing amounts $(0.0625,0.125,0.25,0.5,1,2,4,8,16$ and $24 \mathrm{ng})$ of $\left[{ }^{125} \mathrm{I}\right]$-labelled oLH or $\left.\mathrm{I}^{125} \mathrm{I}\right]$-labelled hCG were incubated in triplicate for $22 \mathrm{~h}$ at $4^{\circ} \mathrm{C}$ with testicular membranes equivalent to $1.5 \mathrm{mg}$ of protein and assay buffer to a final volume of $500 \mu \mathrm{l}$ per tube. The assay buffer was Tris- $\mathrm{HCl}\left(25 \mathrm{mmol} \mathrm{l}^{-1}\right.$, $\mathrm{pH} 7.5$ ) containing $10 \mathrm{mmol} \mathrm{MgCl}{ }_{2} 1^{-1}$ and $1 \mathrm{mg} \mathrm{BSA} \mathrm{ml}{ }^{-1}$. Nonspecific binding was determined in the presence of $1 \mu \mathrm{g}$ of unlabelled hCG or oLH per tube, respectively. The binding of hormone and receptor was stopped by adding $2 \mathrm{ml}$ of cold assay buffer followed by centrifugation at $3000 \mathrm{~g}$ for $20 \mathrm{~min}$ at $4^{\circ} \mathrm{C}$. Radioactivity was determined in the pellets (counts bound) and supernatants (counts free) in a Packard 5160 auto- $\gamma$ scintillation spectrometer with an efficiency of $58.2 \%$.

The maximum binding capacity of labelled hormones used in the assays was assessed by incubating 0.05-0.5 ng of each hormone with an excess of sheep testicular membrane preparations and were found to be $17.2 \%$ for $\left[{ }^{125} \mathrm{I}\right.$-labelled oLH and $21.3 \%$ for $\left[^{125} \mathrm{I}\right.$-labelled hCG. All binding assays were performed with a single preparation of each labelled hormone.

\section{Receptor binding capacity and $\mathrm{K}_{d}$ values}

Receptor binding capacity and the dissociation constant for each hormone were estimated by Scatchard plot using the computer program Enzfitter (Elsevier-BIOSOFT, Cambridge, UK). For the purpose of these analyses, the amount of radioactivity specifically bound was obtained by subtracting the nonspecific binding counts from the counts bound (counts in the pellets). Specifically bound radioactivity was transformed into ng of hormone using the specific activity and the equivalence of $1 \mu \mathrm{Ci}=2.2 \times 10^{6}$ d.p.m. The amount of free hormone was calculated by subtracting the amount of hormone specifically bound from the total amount of hormone added to the assay tube. Molar concentrations of free and bound hormone were estimated using the molecular masses for $\mathrm{oLH}$ and hCG given above. 
Table 1. Least-squares means for testis volume (TV) and percentage volumes of seminiferous tubules (ST), interstitium (INTS), vascular tissue (VT), Leydig cells (LC) and other components of the testicular interstitium of Rambouillet rams from lines selected for low (LL) or high (HL) reproductive rates and from a random-bred control line $(\mathrm{CL})$

\begin{tabular}{lccccccc}
\hline Selection line & $n$ & TV $\left(\mathrm{cm}^{3}\right)$ & ST (\%) & INTS (\%) & VT (\%) & LC (\%) & Other (\%) \\
\hline LL & 8 & 91.0 & 80.7 & 19.3 & $4.6^{\mathrm{a}}$ & 2.3 & 12.5 \\
HL & 6 & 85.2 & 81.6 & 18.4 & $3.6^{\mathrm{b}}$ & 2.7 & 12.0 \\
CL & 7 & 86.5 & 82.2 & 17.8 & $3.6^{\mathrm{b}}$ & 2.2 & 11.8 \\
SEM & & 24.8 & 3.4 & 3.4 & 0.8 & 0.5 & 2.7 \\
\hline
\end{tabular}

${ }^{a b}$ Values within columns with different superscripts are significantly different $(P<0.05)$.

'Pooled SEM.

\section{Statistical analyses}

Data for gross and histomorphological characteristics were analysed by analyses of variance for a completely randomized design using the General Linear Models (GLM) procedure of SAS (1987). The time of orchidectomy or location within the testis or their interactions with the type of line did not influence $(P>0.10)$ any histomorphological characteristic; thus the model included only line. The same analyses were used for $\mathrm{oLH}$ and $\mathrm{hCG}$ receptor characteristics. The main effect means were compared orthogonally (control line versus selected lines, and low line versus high line). Four rams did not exhibit an increase in testosterone secretion 2,3 or $4 \mathrm{~h}$ after adding gonadotrophin compared with that after $1 \mathrm{~h}$ of incubation. These rams were considered non-responders and were not included in testosterone analyses. Data for testosterone secretion per hour per gram of testicular parenchyma were analysed by a split-split-plot design for each gonadotrophin using the GLM procedure of SAS (1987). The error term to test the type of line was animal within line. The error term to test dosage and the interaction of dosage with line was animal within line by dosage. This characteristic was also analysed with a model that included gonadotrophins. The main effects of line and gonadotrophin were tested using the error term animal within line by gonadotrophin by dosage.

The total testosterone secretion per gram of testicular parenchyma was calculated by summing the testosterone concentrations at each hour of incubation. The total testosterone secretion for each gonadotrophin was analysed by analysis of variance for a split-plot design. The main plot was line and the subplot included dosage and the interaction of line with dosage. Line was tested with animal within line as the error term. This characteristic was also analysed with a model that included gonadotrophin. The main effects were tested with animal within line by gonadotrophin as the error term.

\section{Results}

\section{Gross and histomorphological characteristics}

The scrotal circumference did not differ $(P>0.05)$ between trials or among lines and averaged $25.7 \pm 1.6(\mathrm{SD}) \mathrm{cm}$. In Trial 1 , paired testis mass, and in Trial 2, left testis mass did not differ $(P<0.05)$ among lines and averaged $189.3 \pm 11.4 \mathrm{~g}$ and
$91.5 \pm 4.5 \mathrm{~g}$, respectively. Values for right and left testicular tone did not differ $(P>0.05)$ among lines in Trial 2 and were $1.6 \pm 0.18$ and $1.6 \pm 0.14$ units, respectively.

The seminiferous tubule diameter did not differ $(P>0.05)$ among lines. Mean diameters and the number of seminiferous tubules counted were: $169.6 \pm 7.5 \mu \mathrm{m}, 158 \pm 76 ; 178.2 \pm$ $8.7 \mu \mathrm{m}, 160 \pm 3 \mathrm{I}$; and $182.2 \pm 8.0 \mu \mathrm{m}, 149 \pm 26$ for $\mathrm{LL}, \mathrm{HL}$ and $\mathrm{CL}$ rams, respectively.

The testis volume and percentage volumes of seminiferous tubules, interstitium or components of the interstitium other than Leydig cells did not differ $(P>0.05)$ among lines (Table 1$)$. The percentage volume of Leydig cells did not differ $(P>0.05)$ among lines; however, the percentage volume of vascular tissue was greater in $\mathrm{LL}(P<0.05)$ rams than in $\mathrm{HL}$ or $\mathrm{CL}$ rams (Table 1). Percentage volumes of vascular tissue did not differ $(P>0.05)$ between $\mathrm{HL}$ and $\mathrm{CL}$ rams.

Leydig cell volume, the volume of Leydig cell nuclei, the number of Leydig cells per gram of testis, the total number of Leydig cells per testis, and the total volume of Leydig cells in the testis did not differ $(P>0.05)$ among lines (Table 2$)$.

\section{Receptor binding capacity and $\mathrm{K}_{d}$ values}

The binding capacities of both $\left[{ }^{125} \mathrm{I}\right]$-labelled oLH and $\left[{ }^{125} \mathrm{I}\right]$-labelled hCG to testicular membrane preparations was saturable for rams in each line. Of the 23 rams evaluated, membrane preparations from only three rams exhibited saturation curves that could not be fitted directly to the binding equation for a one ligand, one binding site model.

The binding capacities of testicular preparations for oLH and hCG expressed as fmol $\mathrm{mg}^{-1}$ of membrane protein, $\mathrm{fmol}^{-1}$ of parenchyma, or pmol per testis did not differ $(P>0.05)$ among lines (Table 3 ). The number of binding sites per Leydig cell for oLH and hCG did not differ $(P>0.05)$ among lines (Table 3). Capacity, regardless of how it was expressed, was greater $(P<0.05)$ for oLH binding than for hCG binding within each line of rams (Table 3). The capacity per gram of testicular parenchyma and the number of receptor sites per Leydig cell for oLH were approximately 1.5 times higher than for hCG.

Dissociation constants $\left(K_{\mathrm{d}} \times 10^{12} \mathrm{~mol}^{-1}\right)$ for both oLH and hCG binding sites did not differ $(P>0.05)$ among lines (Table 4). The $K_{d}$ values for oLH binding sites were approximately six times higher $(P<0.05)$ than for hCG binding sites within each line (Table 4). 
Table 2. Least-squares means for Leydig cell (LC) characteristics in Rambouillet rams from lines selected for low (LL) or high (HL) reproductive rates and from a random-bred control line (CL)

\begin{tabular}{lcccccc}
\hline $\begin{array}{l}\text { Selection } \\
\text { line }\end{array}$ & $n$ & $\begin{array}{c}\text { LC volume } \\
\left(\mu \mathrm{m}^{3}\right)\end{array}$ & $\begin{array}{c}\text { LC nuclei volume } \\
\left(\mu \mathrm{m}^{3}\right)\end{array}$ & $\begin{array}{c}\text { Total volume of LC } \\
\left(\mathrm{cm}^{3}\right)\end{array}$ & $\begin{array}{c}\text { Number of LC per testis } \\
\left(\times 10^{9}\right)\end{array}$ & $\begin{array}{c}\text { Number of LC per g of testis } \\
\left(\times 10^{6}\right)\end{array}$ \\
\hline $\mathrm{LL}$ & 8 & 943.5 & 207.5 & 2.0 & 2.129 & 23.240 \\
$\mathrm{HL}$ & 6 & 1083.6 & 226.5 & 2.3 & 2.210 & 24.887 \\
$\mathrm{CL}$ & 6 & 917.5 & 205.9 & 1.9 & 2.015 & 23.813 \\
$\mathrm{SEM}^{\mathrm{a}}$ & & 151.8 & 28.3 & 0.6 & 0.574 & 6.263 \\
\hline
\end{tabular}

aPooled SEM.

Table 3. Least-squares means for characteristics of LH and hCG testicular receptors of Rambouillet rams from lines selected for low (LL) or high (HL) reproductive rates and from a random-bred control line (CL)

\begin{tabular}{|c|c|c|c|c|c|c|c|c|c|}
\hline \multirow{2}{*}{$\begin{array}{l}\text { Selection } \\
\text { line }\end{array}$} & \multirow[b]{2}{*}{$n$} & \multicolumn{2}{|c|}{$\begin{array}{c}\text { Capacity per mg } \\
\text { of membrane } \\
\text { protein (fmol) }\end{array}$} & \multicolumn{2}{|c|}{$\begin{array}{l}\text { Capacity per } g \\
\text { of parenchyma } \\
(\mathrm{fmol})\end{array}$} & \multicolumn{2}{|c|}{$\begin{array}{l}\text { Capacity } \\
\text { per testis } \\
\text { (pmol) }\end{array}$} & \multicolumn{2}{|c|}{$\begin{array}{l}\text { Receptors per } \\
\text { Leydig cell } \\
\left(\times 10^{3}\right)\end{array}$} \\
\hline & & $\mathrm{oLH}^{\mathrm{a}}$ & hCG & $\mathrm{oLH}^{\mathrm{a}}$ & hCG & $\mathrm{oLH}^{\mathrm{a}}$ & hCG & $\mathrm{oLH}^{\mathrm{a}}$ & hCG \\
\hline LL & 6 & 45.3 & 17.2 & 383.2 & 147.1 & 34.8 & 13.3 & 10.21 & 3.85 \\
\hline $\mathrm{HL}$ & 7 & 62.6 & 23.2 & 554.4 & 208.7 & 47.7 & 18.5 & 15.29 & 5.69 \\
\hline CL & 7 & 48.1 & 19.9 & 378.8 & 157.6 & 34.8 & 13.6 & 9.12 & 3.70 \\
\hline $\operatorname{SEM}^{b}$ & & 23.5 & 11.8 & 172.1 & 102.2 & 16.7 & 9.2 & 4.80 & 2.67 \\
\hline
\end{tabular}

aValues are significantly different $(P<0.05)$ between oLH and hCG, within selection lines for each trait.

${ }^{\text {b} P o o l e d ~ S E M . ~}$

Table 4. Least-squares means for dissociation constants $\left(K_{d}\right.$ values) for oLH and hCG testicular receptors of Rambouillet rams from lines selected for low (LL) or high (HL) reproductive rates and from a random-bred control line (CL)

\begin{tabular}{lccc}
\hline & & \multicolumn{2}{c}{$K_{\mathrm{d}}\left(\times 10^{-12} \mathrm{~mol} \mathrm{l}^{-1}\right)$} \\
\cline { 3 - 4 } $\begin{array}{l}\text { Selection } \\
\text { line }\end{array}$ & $n$ & $\mathrm{oLH}^{\mathrm{a}}$ & $\mathrm{hCG}$ \\
\hline $\mathrm{LL}$ & 6 & 87.3 & 12.9 \\
$\mathrm{HL}$ & 7 & 82.5 & 13.8 \\
$\mathrm{CL}$ & 7 & 133.8 & 26.1 \\
SEM $^{\mathrm{b}}$ & & 88.6 & 11.4 \\
\hline
\end{tabular}

${ }^{\mathrm{a}}$ Values are significantly different $(P<0.05)$ between oLH and hCG within each line.

booled SEM.

\section{Gonadotrophin-stimulated testosterone secretion in vitro}

Testosterone secretion stimulated by oLH in vitro per gram of testis per hour did not differ $(P>0.05)$ among lines over time (Fig. 1a). However, there was a line by time interaction $(P<0.05)$ for hCG-stimulated testosterone secretion in vitro per gram of testis (Fig. Ib). LL and HL rams secreted more $(P<0.05)$ testosterone after $2 \mathrm{~h}$ of incubation compared with after $1 \mathrm{~h}$. Concentrations of testosterone after $3 \mathrm{~h}$ did not differ $(P>0.05)$ relative to that after $2 \mathrm{~h}$ but had decreased at $4 \mathrm{~h}$ of incubation in LL and HL rams. Testosterone secretion in CL rams did not change $(P>0.05)$ during the first $2 \mathrm{~h}$, but had decreased $(P<0.05)$ by $3 \mathrm{~h}$ and again $(P<0.05)$ by $4 \mathrm{~h}$ of incubation. During every hour of incubation HL rams secreted significantly more $(P<0.05)$ testosterone than did LL rams, with the exception of the value recorded after $3 \mathrm{~h}$.

Testosterone secretion over time for equimolar dosages of oLH and hCG did not differ $(P>0.05)$ between gonadotrophins and there was no line by dosage by gonadotrophin interaction $(P>0.05)$ for testosterone secretion per hour.

Total oLH-stimulated and hCG-stimulated testosterone increased $(P<0.05)$ as the dosage of gonadotrophin increased (Table 5). The total amount of testosterone secreted per gram of testis did not differ $(P>0.05)$ between gonadotrophins at dosages of 0,46 and $4600 \mathrm{pmol} \mathrm{l}^{-1}$ (Table 5). However, 4.6 pmol hCG $\mathrm{I}^{-1}$ stimulated the secretion of significantly more $(P<0.05)$ testosterone than did 0 pmol hCG $\mathrm{I}^{-1}$, whereas the same concentration of oLH did not significantly increase $(P>0.05)$ testosterone secretion compared with 0 pmol oLH ${ }^{-1}$ (Table 5). The type of line did not affect $(P>0.05)$ total testosterone secretion and there was no $(P>0.05)$ line by gonadotrophin interaction.

\section{Discussion}

Curry et al. (1993) reported that neither right, left nor paired testis mass or scrotal circumference differed among rams of 


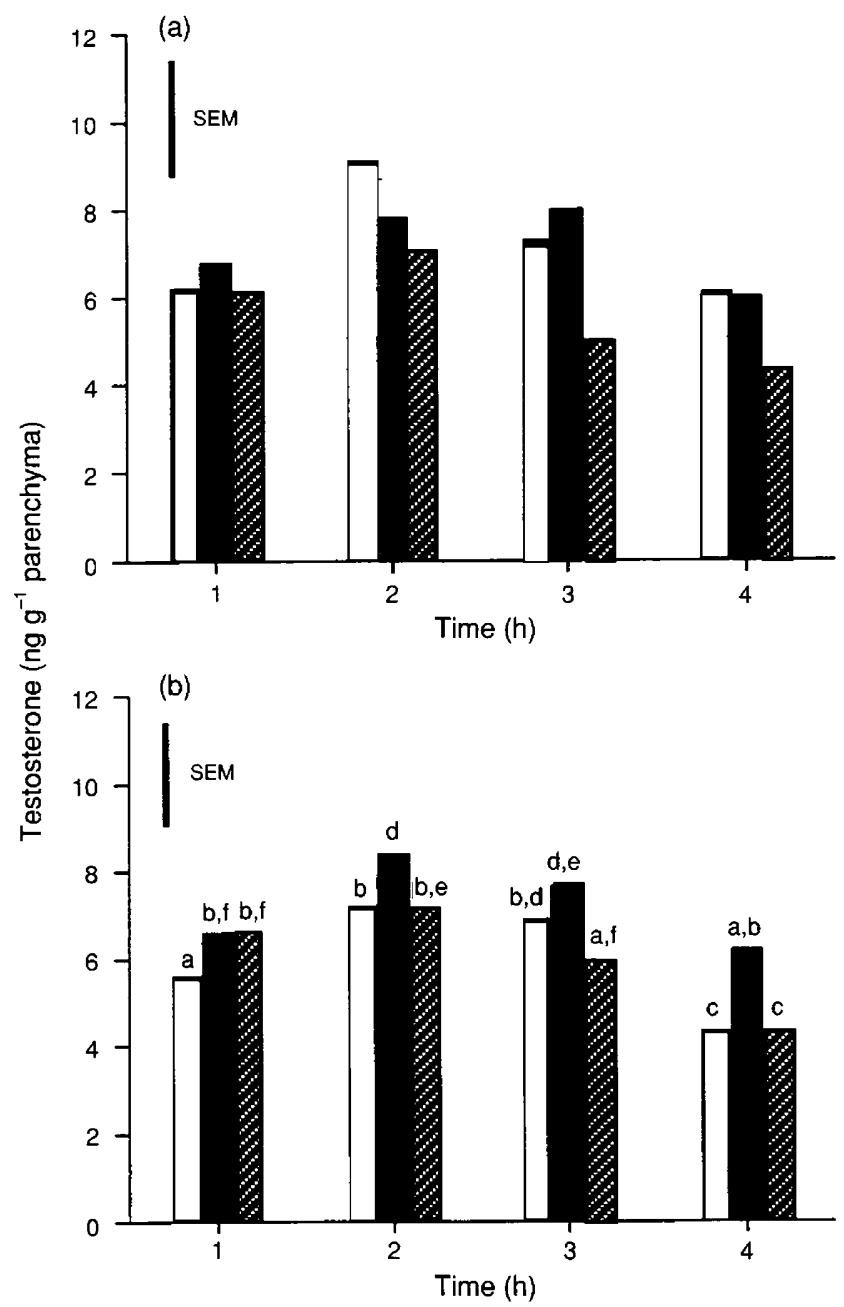

Fig. 1. Interactions between ram selection line and time for (a) oLH-stimulated $(P=0.07)$ and $(b)$ hCG-stimulated $(P<0.05)$ testosterone secretion by testicular parenchyma for Rambouillet rams from lines selected for low $(\square)$ or high $(\boldsymbol{\square})$ reproductive rates and for rams from a random-bred control line ( $)$. Bars without common letters are significantly different $(P<0.05)$

these lines after 13 years of selection. In the present study, using rams of the same lines and ages, we confirm and extend this finding after 20 years of selection. Scrotal circumference or testis mass may not be highly genetically correlated with ovulation rate or litter size in these lines. These findings are in agreement with other studies that demonstrate that scrotal circumference or testes mass are not always associated with the ovulation rate of ewes (Haley et al., 1990; Hochereau-de Reviers et al., 1990b; Matos and Thomas, 1992).

Lines varied little in the histomorphological characteristics of their testes, except that the volume occupied by vascular tissue was significantly higher in LL rams than in HL rams. The biological importance of this finding is not clear, especially since the volume occupied by the interstitium and volumes occupied by interstitial components other than vascular tissue did not differ among lines. The degree of vascularity of testicular interstitium could affect testosterone synthesis, secretion and transport in the testis (Fawcett et al., 1973). Whether the increased proportion of testicular interstitium occupied by
Table 5. Least-squares means for total testosterone secretion per gram of testicular parenchyma in vitro after stimulation by equimolar dosages of $\mathrm{LH}$ or hCG in Rambouillet rams

\begin{tabular}{ccc}
\hline $\begin{array}{l}\text { Dosage of } \\
\text { gonadotrophin } \\
\left(\text { pmol } 1^{-1}\right)\end{array}$ & $\begin{array}{c}\text { Total oLH-stimulated } \\
\text { testosterone secretion } \\
\left(\mathrm{ng} \mathrm{g}^{-1} \text { parenchyma) }\right. \\
(n=21)\end{array}$ & $\begin{array}{c}\text { Total hCG-stimulated } \\
\text { testosterone secretion } \\
\left(\mathrm{ng} \mathrm{g}^{-1} \text { parenchyma) }\right. \\
(n=21)\end{array}$ \\
\hline 0 & $16.5^{\mathrm{a}}$ & $16.6^{\mathrm{a}}$ \\
4.6 & $19.5^{\mathrm{a}}$ & $22.5^{\mathrm{b}}$ \\
46 & $28.1^{\mathrm{c}}$ & $28.3^{\mathrm{c}}$ \\
4600 & $35.6^{\mathrm{d}}$ & $34.9^{\mathrm{d}}$ \\
$\mathrm{SEM}^{\mathrm{e}}$ & 5.7 & 5.7 \\
\hline
\end{tabular}
abcd Values within columns with different superscripts are significantly different
$(P<0.05)$.
ePooled SEM.

vascular tissue in LL rams influences testosterone secretion in vivo in LL rams was not evaluated in the present study.

Results of the binding studies of this experiment indicate that selection for or against reproductive rate in females of these lines has not altered oLH or hCG binding capacity, the number of Leydig cell receptor sites in, or affinity of receptor sites for, homologous or heterologous gonadotrophins (oLH or hCG) in males of these lines. This result is similar to that of Hochereau-de Reviers et al. (1990b), who reported that Ile de France rams (a prolific breed) and Romanov rams (a less prolific breed) do not differ in their LH-binding capacity per Leydig cell.

Within each line, the $K_{\mathrm{d}}$ value for the binding of oLH to its receptors was approximately six times higher than the $K_{\mathrm{d}}$ value for $\mathrm{hCG}$, and binding capacities were approximately three times higher for oLH than for hCG. These results agree in part with those of Sairam et al. (1988), who found higher binding capacities for oLH than for hCG but similar $K_{\mathrm{d}}$ values for both gonadotrophins in testicular preparations from rams. In contrast, Huhtaniemi and Catt (1981) reported similar binding capacities for oLH and hCG but a lower $K_{d}$ value for hCG than for oLH in rat testicular preparations. They observed that the binding of oLH in the rat fit a model with two different binding sites: one with a high affinity (low $K_{d}$ ) that constituted about $20 \%$ of the oLH receptors, and the other with low affinity (high $K_{d}$ ) that constituted $80 \%$ of the oLH receptors. In our study, binding data for hCG fit exclusively a one ligand, one-binding site model and, for the most part, so did the binding data for $\mathrm{oLH}$, with the exception of three rams that appeared to fit a one ligand, two-binding site model.

The line by time interactions for hCG-stimulated testosterone secretion in vitro indicates that selection has altered the manner in which Leydig cells of rams of these lines respond to gonadotrophin stimulation over time. Although not significant at the $P<0.05$ level, the same trend was apparent for oLHstimulated testosterone secretion in vitro. HL rams secreted more hCG-stimulated testosterone during every hour of culture (except the third) than did LL rams. The mechanisms by which selection for reproductive rate in females has changed the pattern of response of the testis to $\mathrm{hCG}$ and possibly to $\mathrm{oLH}$ in vitro are not clear. It is known that testosterone 
synthesis and secretion by the testicular parenchyma can be influenced by numerous intracellular and extracellular factors (Hall, 1988). Ewing et al. (1979) suggested that differences between certain mammals in LH-stimulated testosterone secretion are not related to differences in Leydig cell mass. Furthermore, Zirkin et al. (1980) found that differences in testosterone secretion among various species of male could be accounted for by differences in the volume of smooth endoplasmic reticulum in Leydig cells. The possibility that HL rams secrete more testosterone in vitro in response to hCG because their Leydig cells contain a greater volume of this type of endoplasmic reticulum than do Leydig cells of LL or CL rams remains to be examined.

Although the capacity of the oLH receptor was higher than the capacity of the hCG receptor, total oLH- and hCGstimulated testosterone secretion did not differ in two out of three equimolar dosages of gonadotrophin. It is possible that the higher affinity of the hCG receptor could have compensated for its lower capacity, thereby stimulating testosterone secretion to the same degree as oLH. Stimulation of testosterone secretion exhibited after administering the lowest dosage of hCG tested may be explained, at least partially, by the higher affinity of hCG for its receptor, which, according to Huhtaniemi and Catt (1981), contributes to the well-known high bioactivity of this hormone. These results also indicate that the ram testis seems to be more sensitive to hCG than to oLH.

In conclusion, selection for or against reproductive rate in Rambouillet ewes has not altered gross or most histomorphometric characteristics of the testis of male offspring, with the exception that selection against reproductive rate increases the proportion of testicular volume occupied by vascular tissue within the interstitium. Furthermore, selection has not altered total oLH- and hCG-stimulated testosterone secretion in vitro or testicular oLH and hCG receptor affinity or capacity of male offspring.

This paper is contribution no. J-2816 of the Montana Agricultural Experiment Station. The research was supported in part by an SR-CRSP grant from the Agency for International Development, Title XII, Grant no. AID/DSAN/XII-G-0049. Ovine LH and hCG were generously provided by the NIDDK, the National Hormone and Pituitary Program, and the University of Maryland Medical School.

\section{References}

Abercrombie M (1946) Estimation of nuclear population from microtome section Anatomical Record $94239-249$

Allrich RD, Christenson RK, Ford JJ and Zimmerman DR (1983) Pubertal development of the boar: age related changes in testicular morphology and in vitro production of testosterone and estradiol-17ß Biology of Reproduction $28902-909$

Berardinelli JG, Burfening PJ, Cárdenas $\mathrm{H}$ and Adair R (1989) In vitro technique for evaluating sensitivity of testicular tissue to human chorionic gonadotropin (hCG) in rams Proceedings of the Western Section of the American Society of Animal Science $\mathbf{4 0} 280-283$

Bindon BM and Turner HN (1974) Plasma LH of the prepubertal lamb: a possible early indicator of fecundity Journal of Reproduction and Fertility 39 $85-88$

Bindon BM, Piper LR, Cummins LJ, O'Shea T, Hillard MS, Findlay JK and Robertson DM (1985) Reproductive endocrinology of prolific sheep: studies of the Booroola Merino. In Genetics of Reproduction in Sheep pp 217-235 Eds RB Land and DW Robertson. Butterworths, London
Byerley DJ, Bertrand JK, Berardinelli JG and Kiser TE (1990) Testosterone and luteinizing hormone response to $\mathrm{GnRH}$ in yearling bulls of different libido Theriogenology $341041-1049$

Carr WR and Land RB (1975) Plasma luteinizing hormone levels and testis diameter of ram lambs of different fertility Journal of Reproduction and Fertility $42325-333$

Chubb C (1992) Genes regulating testis size Biology of Reproduction 47 29-36

Curry KC, Berardinelli JG, Burfening PJ and Adair R (1993) Selection for reproductive rate in females and feeding regimen on testicular traits and epididymal sperm reserves in Rambouillet rams Small Ruminant Research 11 $257-265$

Ewing LL, Zirkin BR, Cochran RC, Kromann N, Peters C and Ruiz-Bravo N (1979) Testosterone secretion by rat, rabbit, guinea pig, dog and hamster testis perfused in vitro: correlation with Leydig cell mass Endocrinology 105 $1135-1142$

Fawcett DW, Neaves WB and Flores M (1973) Comparative observations on intertubular lymphatics and the organization of the interstitial tissue of the mammalian testis Biology of Reproduction 9 500-532

Glauert AM (1975) Fixation, dehydration and embedding of biological specimens. In Practical Methods in Electron Microscopy pp 73-110. North-Holland Publishing Company Co., New York.

Haley CS, Lee GJ, Fordyce M, Baxter G, Land RB and Webb R (1989) Study of LH response to $\mathrm{GnRH}$ in the young male as a criterion of genetic merit for female reproduction in sheep Journal of Reproduction and Fertility 86 119-133

Haley CS, Lee GJ, Ritchie M and Land RB (1990) Direct response in males and correlated response for reproduction in females to selection for testicular size adjusted for body weight in young male lambs Journal of Reproduction and Feritility 89 383-396

Hall PF (1988) Testicular steroid synthesis: organization and regulation. In The Physiology of Reproduction pp 975-988 Eds E Knobil and JD Neill. Raven Press, New York

Hochereau-de Reviers MT, Copin M, Seck M, Monet-Kuntz C, Corme C, Fontaine I, Perrau C, Elsen JM and Boomarov I (1990a) Stimulation of testosterone production by PMSG injection in the ovine male: effects of breeds and age and application to males carrying or not carrying the ' $F$ ' Booroola gene Animal Reproduction Science 23 21-32

Hochereau-de Reviers MT, Perrau C, Pisselet C, Fontaine I and Monet-Kuntz C (1990b) Comparison of endocrinological and testis parameters in 18-monthold Ile de France and Romanov rams Domestic Animal Endocrinology 7 63-73

Hoffmann EO, Flores TR, Coover J and Garret HB (1983) Polychrome stain for high resolution light microscopy Laboratory Medicine 14 779-781

Huhtaniemi IT and Catt KJ (1981) Differential binding affinities of rat testis luteinizing hormone (LH) receptors for human chorionic gonadotrophin, human LH and ovine LH Endocrinology 108 1931-1938

Knight TW (1984) Testicular growth and size in rams from flocks of different reproductive potential New Zealand Joumal of Agricultural Research 27 179-187

Land RB (1973) The expression of female sex-limited characters in the male Nature 241 208-209

Land RB (1974) Physiological studies and genetic selection for sheep fertility Animal Breeding Abstracts 42 155-158

Land RB and Carr WR (1975) Testis growth and plasma LH concentrations following hemicastration and its relation with female prolificacy in sheep Journal of Reproduction and Fertility 45 495-501

Lunstra DD and Schanbacher BD (1988) Testicular function and Leydig cell ultrastructure in long-term bilaterally cryptorchid rams Biology of Reproduction 38 211-220

Matos CAP and Thomas DL (1992) Physiology and genetics of testicular size in sheep: a review Livestock Production Science 32 1-30

SAS (1987) SAS User's Guide: Statisfics (5th Edn) Statistical Analysis System Institute, Inc., Cary, NC

Sairam MR, Yarney TA, Bhargavi GN and Samford LM (1988) Conformational restrictions of the sheep testicular receptors discriminates pituitary lutropin and placental gonadotropins Journal of Biological Chemistry 263 3706-3712

Schoenian GS and Burfening PJ (1990) Ovulation rate, lambing rate, litter size and embryo survival of Rambouillet sheep selected for high and low reproductive rate Joumal of Animal Science 68 2263-2270

Thimonier J and Pelletier J (1972) The concentration of plasma LH in male and female lambs of high and low prolificacy breed types Journal of Reproduction and Fertility 31498 (Abstract)

Zirkin BR, Ewing LL, Kromann N and Cochran RC (1980) Testosterone secretion by rat, rabbit, guinea pig, $\operatorname{dog}$ and hamster testes perfused in vitro: correlation with Leydig cell ultrastructure Endocrinology 107 1867-1874 